DOI: https://doi.org/10.31933/jemsi.v2i3

Received: 21 November2020, Revised: 15 Desember 2020, Publish: 8 Februari 2021

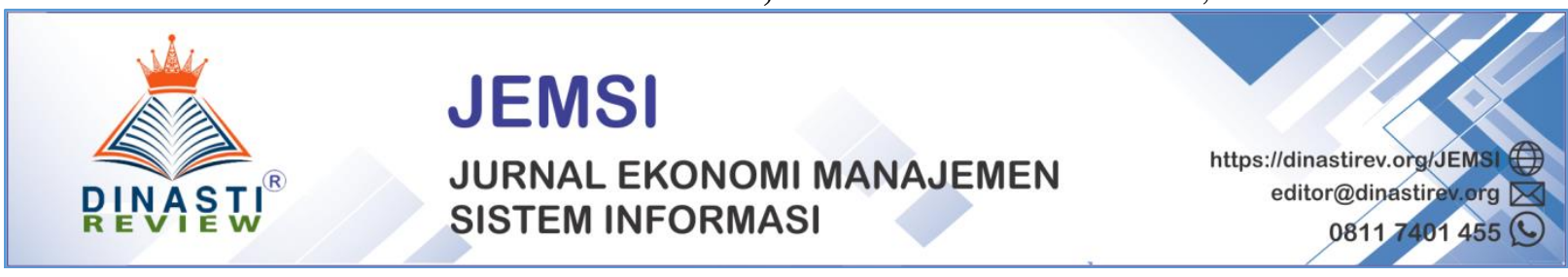

\title{
ANALISA PENILAIAN KINERJA KEUANGAN PT BARAMULTISUKSES SARANA
}

\section{Annisa Ayu Budhiarti}

Fakultas Pasca Sarjana Universitas Mercubuana, Jakarta, annisaayu0@ gmail.com

\section{Corresponding Author: Annisa Ayu Budhiarti}

Abstrak: Perhitungan kinerja keuangan ini dilakukan untuk mengetahui baik atau buruknya hasil kinerja keuangan perusahaan. Perusahaan yang terorganisir dengan baik selalu membuat laporan keuangan seperti neraca rugi laba. Penelitian ini menggunakan data sekunder dengan populasi Laporan kuangan PT. Baramulti Sukses Sarana, Tbk. Variabel yang digunakan dalam analisa ini adalah rasio likuiditas, solvabilitas, aktivitas, profitabilitas dan Du Pont System. Kesimpulan dari penelitian ini adalah PT. Baramulti Sukses Sarana memiliki kinerja yang masih kurang baik karena dari keempat rasio keuangan menunjukkan angka yang fluktuatif yang berarti perusahaan belum mampu melakukan efektivitas semua sumber daya perusahaan dan menghasilkan laba secara maksimal setiap tahunnya.

Kata Kunci: Likuiditas, Solvabilitas, Aktivitas, Profitabilitas, Analisis Du Pont System

\section{PENDAHULUAN}

Negara Indonesia memiliki kekayaan alam dan hasil bumi yang sangat beragam baik hasil laut, hutan maupun hasil tambang dan diolah hasilnya oleh Negara maupun pihak swasta lokal dan asing baik Perusahaan berbadan hukum maupun perorangan. Sebagian besar dapat dilhat perusahaan-perusahaan yang terdaftar di Bursa Efek Indonesia yang mengelolah kekayaan alam dengan berbagai sektor seperti: sektor laut, sektor pengelolahan hutan, perkebunan, pertambangan dll. Untuk dapat melihat kondisi perusahaan tersebut apakah baik atau buruk, maka diperlukan perhitungan kinerja, khususnya kinerja keuangan. Perhitungan kinerja keuangan ini dilakukan untuk mengetahui baik atau buruknya hasil kinerja keuangan perusahaan, selain itu juga dapat dipakai sebagai alat untuk menilai bagi investor perkembangan perusahaan dimasa yang akan datang.

PT. Baramulti Suksessarana Tbk (BSSR) bergerak dalam bidang pertambangan dan perdagangan batubara, transportasi darat, industri dan konstruksi. Perusahaan memulai kegiatan komersialnya untuk kegiatan perdagangan pada tahun 1990. Tambang batubara perusahaan memasuki tahap produksi pada bulan Juni 2011. Berdasarkan hal tersebut maka permasalahan yang akan dibahas dalam penelitian ini adalah bagaimana kinerja manajemen PT. Baramulti Suksessarana Tbk selama periode 2014 hingga 2019 berdasarkan rasio keuangan. 


\section{KAJIAN PUSTAKA}

\section{Pengertian Laporan Keuangan}

"Laporan Keuangan adalah suatu penyajian terstruktur dari posisi keuangan dan kinerja keuangan suatu entitas". Menurut Ikatan Akuntan Indonesia (2012:5). Laporan keuangan adalah Laporan yang menunjukan kondisi keuangan perusahaan pada saat ini atau periode tertentu. Menurut Kasmir (2014:7). Laporan keuangan adalah bentuk informasi yang disajikan pihak Akuntansi sebagai bentuk pertanggungjawaban manajemen terhadap pihak-pihak yang berkepentingan dengan kinerja Bank yang dicapai selama periode tertentu (Taswan, 2013:39).

Laporan keuangan adalah suatu informasi yang menggambarkan kondisi keuangan suatu perusahaan, dan lebih jauah informasi tersebut dapat dijadikan gambaran kinerja keuangan perusahaan tersebut. Menurut Fahmi (2013:2). Laporan keuangan merupakan rangkaian aktivitas ekonomi perusahaan yang di klasifikasikan pada periode tertentu atau ringkasan dari suatu proses transaksi keuangan yang terjadi selama periode yang bersangkutan. Dan juga dapat dikatakan sebagai produk akuntansi yang penting dan dapat digunakan untuk membuat keputusankeputusan ekonomi bagi pihak internal maupun pihak eksternal perusahaan.

\section{Tujuan Laporan Keuangan}

Menurut PSAK No. 1 Paragraf ke 7 (Revisi 2013), "tujuan laporan keuangan adalah memberikan informasi mengenai posisi keuangan, kinerja keuangan dan arus kas entitas yang bermanfaat bagi sebagian besar kalangan pengguna laporan dalam pembuatan keputusan ekonomi”.

Laporan keuangan juga menunjukkan hasil pertanggungjawaban manajemen atas penggunaan sumber daya yang dipercayakan kepada mereka. Menurut PSAK No. 1 Paragraf ke 7 (Revisi 2013). "dalam rangka mencapai tujuan laporan keuangan, laporan keuangan mnenyajikan informasi mengenai entitas yang meliputi: asset, liabilitas, ekuitas, pendapatan dan beban termasuk keuntungan dan kerugian, kontribusi dari dan distribusi kepada pemilik dalam kapasitasnya sebagai pemilik dan arus kas". Informasi tersebut, beserta informasi lainnya yang terdapat dalam catatan atas laporan keuangan,.

Menurut Kasmir (2012:11) Tujuan laporan keuangan adalah :

1. Memberikan informasi tentang jenis dan jumlah aktiva (harta) yang dimiliki perusahaan saat ini.

2. Memberikan informasi tentang jenis dan jumlah kewajiban dan modal yang dimiliki perusahaan saat ini.

3. Memberikan informasi tentang jenis dan jumlah pendapatan yang diperoleh dalam suatu periode tertentu.

4. Memberikan informasi tentang jumlah biaya dan jenis biaya yang dikeluarkan perusahaan dalam suatu periode tertentu.

5. Memberikan informasi tentang perubahan-perubahan yang terjadi terhadap aktiva, pasiva dan modal perusahaan.

6. Memberikan informasi tentang kinerja manajemen perusahaan dalam suatu periode.

7. Memberikan informasi tentang catatancatatan atas laporan keuangan.

8. Informasi keuangan lainnya

Tujuan laporan keuangan adalah untuk menyediakan informasi mengenai sumber-sumber ekonomik perusahaan, kewajiban kewajibannya, dan informasi mengenai modal pemilik. Tujuan 
tersebut dimaksudkan untuk membantu investor kreditor serta pemakai lain dalam mengidentifikasi kekuatan dan kelemahan finansial perusahaan dan untuk mengetahui likuiditas dan solvabilitas perusahaan.

\section{Jenis-Jenis Laporan Keuangan}

Menurut Kasmir (2014: 7) Ada beberapa jenis laporan keuangan, yaitu:

1. Balance Sheet (Neraca), yaitu laporan keuangan yang menunjukan posisi keuangan perusahaan pada tanggal tertentu,artinya dari posisi keuangan dimaksudkan adalah posisi jumlah dan jenis aktiva( harta), Pasiva (kewajiban danekuitas) suatu perusahaan.

2. Income Statement (Laporan Laba Rugi), yaitu merupakan laporan keuangan yang menggambarkan hasil usaha perusahaan yang dalam satu periode tertentu. Dalam laba rugi tergambar jumlah pendapatan dan sumber-sumber pendapatan yang diperoleh. Kemudian juga tergambar jumlah biaya danjenis-jenis biaya yang dikeluarkan selama periode tertentu.

3. Laporan perubahan Modal, yaitu merupakan laporan yang berisi jumlah dan jenis modal yang dimiliki pada saat ini ,kemudian laporan ini juga menjelaskan perubahan modal dan sebab-sebab terjadinya perunan modal di perusahaan.

4. Laporan Arus Kas, yaitu merupakan laporan uang menunjukan semua aspek yang berkaitan dengan kegiatan perusahaan, baik yang berpengaruh langsung atau tidak langsung terhadap kas.

5. Laporan catatan atas laporan keuangan merupakan laporan yang memberikan informasi apabila ada laporan keuangan memerlukan penjelasan tertentu.

Menurut PSAK No. 1 Paragraf 49 (Revisi 2013), "laporan keuangan yang lengkap terdiri dari komponen-komponen berikut ini:

a. Laporan posisi keuangan(neraca),

b. Laporan laba rugi dan Penghasilan komprehensif lainnya,

c. Laporan perubahan ekuitas,

d. Laporan arus kas,

e. Catatan atas laporan keuangan.

f. Laporan posisi keuangan pada awal periode Komperatif.

\section{Analisa Laporan Keuangan}

Analisa laporan keuangan adalah analisa laporan keuangan yang terdiri dari penelaahan atau mempelajari dari padahubungan dan tendensi atau kecendrungan (trend) untuk menentukan posisi keuangan dan hasil opersi dan perkembangan perusahaan yang bersangkutan, menurut Munawir (2010: 35)

\section{Teknik Analisa Laporan Keuangan}

Menurut Munawir (2010:36-37) Ada beberapa teknik dalam menganalisa Laporan keuangan :

1. Analisa perbandingan laporan keuangan

2. Trend atau tendensi atau posisi dan kemajuan keuangan perusahaan yang dinyatakan dalam prosentase (Trend Percentage Analiysis)

3. Laporan dengan prosentase per komponen (Common Size Statement)

4. Analisis sumber dan penggunaan modal kerja

5. Analisis sumber dan penggunaan kas (Cash Flow Statement Analysis) 
6. Analisis Rasio

7. Analisis Perubahan Laba Kotor(Gross Profit Analysis)

8. Analisis Break Even

\section{Pengertian Rasio Keuangan}

Rasio keuangan merupakan kegiatan membandingkan angka-angka yang ada dalam laporan keuangan dengan cara membagi satu angka dengan angka yang lainnya. Menurut Kasmir (2014: 104) Misalnya antara hutang dan modal, antara kas dan total asset, antara harga pokok produksi dengan total penjualan dan sebagainya.

\section{Jenis-Jenis Rasio Keuangan}

Berikut ini beberapa jenis rasio keuangan, yaitu :

1. Rasio Likuiditas (Liquidity Ratio)

Adalah rasio yang menggambarkan kemampuan perusahaan dalam memenuhi kewajiban (utang) jangka pendek. Dalam jenis-jenis rasio likuiditas, yang sering digunakandalam menganalisa laporan keuangan adalah : rasio lancar, rasio cepat, rasio, kas, rasio perputaran kas dan Inventory to Net Working Capital (Kasmir, 2013:133)

a. Rasio Lancar (Current Ratio)

Rasio lancar merupakan rasio untuk mengukur kemampuan perusahaan dalam membayar kewajiban jangka pendek atau utang yang segera jatuh tempo pada saat ditagih keseluruhan.

Rumus :

Rasio Lancar $=\frac{\text { Aktíva Lancar }}{\text { Hutang Lancar }}$

Rumus : Menurut Kepmen BUMN No.Kep-100/MBU/2002

Current Ratio $=\frac{\text { Current Asset }}{\text { Current Liabilities }} \times 100 \%$

b. Rasio Cepat (Quick Ratio)

Rasio cepat merupakan rasio yang menunjukkan kemampuan perusahaan memenuhi (membayar) kewajiban atau utang lancar (utang jangka pendek) dengan aktiva lancar tanpa memperhitungkan nilai persediaan (inventory), artinya nilai persediaan kita abaikan, dengan cara dikurangi dari nilai total aktiva lancar. (Kasmir, 2014:136)

c. Rasio Kas (Cash Ratio)

Rumus :

Kepmen BUMN No.Kep-100/MBU/2002

Cash Ratio $=\frac{\text { Kas+Bank }+ \text { Surat berharga Jangka Pendek }}{\text { Current Liabilities }} \times 100 \%$

2. Rasio Aktivitas

Adalah rasio yang digunakan untuk mengukur efisiensi / efektivitas perusahaan dalam menggunakan aktiva yang dimilikinya. Dalam analisa aktivitas rasio yang digunakan adalah :

a. Rasio Perputaran Persediaan (Inventory Turn Over )

Rasio perputaran persediaan, merupakan rasio yang digunakan mengukur berapa kali dana yang ditanam dalam sediaan (Inventory) ini berputar dalam suatu periode.

Rumus : 
Inventory Turn-over $=\frac{\text { Penjualan }}{\text { Sediaan }} \times 1$ kali

Rumus :

Kepmen BUMN No.Kep-100/MBU/2002

Perputaran Persediaan $=\frac{\text { Total Persediaan }}{\text { Total Pendapatan Uasaha }} \times 365$ Hari

b. Rasio Perputaran Piutang (Receivable Turn Over)

Merupakan Rasio yang digunakan untuk mengukur berapa lama penagihan piutang selama satu periode atau berapa kali dana ditanamkan dalam piutang .

Rumus :

Receivable Turn-Over $=\frac{\text { Penjualan }}{\text { Piutang }} \times 1$ kali

c. Collection Periods (CP)

Rumus :

Kepmen BUMN No.Kep-100/MBU/2002

Collection Periods $=\frac{\text { Total Piutang Uasaha }}{\text { Total Pendapatan Uasaha }} \times 365$ Hari

d. Rasio Perputaran Total Aktiva(Total Asset Turn Over )

Merupakan Rasio yang digunakanuntuk mengukur perputaran semua aktiva yang dimiliki perusahaan dan mengukur berapa jumlah penjualan yang diperolehdaritiaprupiah aktiva. Rumus :

Total Asset Turn-over $=\frac{\text { Penjualan }}{\text { Total Asset }} \times 1$ kali

Kepmen BUMN No.Kep-100/MBU/2002

TATO $=\frac{\text { Total Pendapatan }}{\text { Capital Employed }} \times 100 \%$

3. Rasio Solvabilitas (Leverage Ratio)

Adalah rasio yang digunakan untuk mengukur sejauh mana aktiva perusahaan dibiayai dengan utang, artinya berapa besar beban utang yang ditanggung perusahaan dibandingkan dengan Aktiva. Menurut Kasmir (2013:151) rasio yang digunakan adalah :

a. Rasio Hutang Terhadap Aktiva ( Total Debt to Asset Ratio)

Rasio ini mengukur seberapa besar aktiva perusahaan dibiayai oleh hutang atau seberapa besar hutang perusahaan berpengaruh terhadap pengelolaan aktiva.

Rumus :

Debt to Asset Ratio $=\frac{\text { Total Hutang(Total Debt) }}{\text { TotalAktiva (Total Assets) }} \times 100 \%$

b. Rasio Total Modal Sendiri terhadap Total Aset( TMS terhadap TA )

Rumus :

Kepmen BUMN No.Kep-100/MBU/2002

TMS terhadap TA $=\frac{\text { Total Modal Sendiri }}{\text { Total Aset }} \times 100 \%$

4. Rasio Profitabilitas

Adalah Rasio untuk menilai kemampuan perusahaan dalam mencari keuntungan. Rasio ini juga memberikan ukuran tingkat efektivitas manajemen suatu perusahaan (Kasmir, 2012:196)

Adapun yang termasuk Rasio Profitabilitas adalah:

a. Hasil pengembalian Investasi (Return on Investment) 
Hasil pengembalian Investasi atau lebih dikenal dengan nama Return on Investment atau Return on Total Assets merupakan rasio yang menunjukan hasil (return) atas jumlah aktiva yang digunakan dalzm perusahaan menurut Kasmir(2013:203). ROI juga merupakan suatu ukuran tentang efektivitas manajemen dalam mengelola investasi.

Rumus :

Return On Investment $=\frac{\text { Earning After and Tax }}{\text { Total Assets }} \times 100 \%$

Kepmen BUMN No.Kep-100/MBU/2002

Return On Investment $=\frac{\text { EBIT }+ \text { Penyusutan }}{\text { Capital Employed }} \times 100 \%$

b. Hasil pengembalian Ekuitas (Return on Equity Ratio)

Hasil pengembalian Ekuitas atau return on equity atau rentabilitas modal sendiri merupakan Rasio untuk mengukur laba bersih sesudah pajak dengan modal sendiri, rasio ini menunjukan efisiensi penggunaan modal sendiri. Semakin tinggi rasio ini semakin baik.

Rumus :

Return On Equity $=\frac{\text { Earning After and Tax }}{\text { Equity }} \times 100 \%$

Rumus :

Kepmen BUMN No.Kep-100/MBU/2002

Return On Equity $=\frac{\text { Laba Setelah Pajak }}{\text { Modal Sendiri }} \times 100 \%$

c. Margin Laba Bersih (Net Profit Margin)

Margin laba bersih adalahukuran persentase dari setiap hasil penjualan sesudah perusahaan membayar pajak.

Rumus :

Net Profit Margin $=\frac{\text { Earning After and Tax }}{\text { Net Sales }} \times 100 \%$

\section{METODE PENELITIAN}

Teknik Pengumpulan Data

Teknik yang digunakan dalam pengumpulan data, yaitu :

1. Data Sekunder

Merupakan data yang diperoleh dari pihak lain seperti BPS, BI, IMF dll. Dalam hal ini peneliti mengumpulkan data dengan cara :

a. Studi Kepustakaan

Yaitu metode pengumpulan dengan cara membaca dan mempelajaran buku-buku litelatur, artikel untuk mendapatkan teori yang diperlukan sehubungan dengan masalah yang akan dibahas.

b. Studi Dokumentasi

Yaitu suatu teknik pengumpulan data yang dilakukan dengan cara mencatat semua hal yang ada hubungannya dengan penelitian ini melalui buku-buku dan laporan tahunan yang dikeluarkan oleh perusahaan.

\section{Populasi dan Sampel Populasi}


Populasi adalah keseluruhan unit yang menjadi objek kegiatan statistik baik yang berupa instansi pemerintahan, lembaga, organisasi, orang, benda maupun objek lainnya. Menurut Rahcmat Trijono (2015: 30). Populasi adalah kumpulan dari semua kemungkinan orang-orang, benda-benda dan ukuran lain, yang menjadi objek perhatian atau kumpulan seluruh objek yang menjadi pehatian. Menurut Suharyadi, Purwanto S.K (2013:21). Adapun populasi dalam penelitian ini adalah Laporan kuangan PT. Baramulti Sukses Sarana, Tbk.

\section{Sampel}

Sampel adalah sebagian unit populasi yang menjadi objek penelitian untuk memperkirakan karakteristik suatu populasi.Menurut Rahcmat Trijono(2015: 30) Sampel adalah suatu bagian dari populasi tertentu yang menjadi perhatian.Menurut Suharyadi, Purwanto S.K (2013:23). Adapun yang dimaksud dengan sampel dalam penelitian ini adalah Laporan keuangan tahunan PT. Baramulti Sukses Sarana, Tbk periode tahun 2014, 2015, 2016, 2017, 2018 dan 2019.

\section{Objek Penelitian}

Objek penelitian ini berupa analisis laporan keuangan pada PT. Baramulti Sukses Sarana, Tbk Periode 2014-2019

\section{HASIL DAN PEMBAHASAN}

1. Rasio Keuangan

a. Rasio Likuiditas

Rasio ini bertujuan untuk menilai kemampuan perusahaan dalam pemenuhan kewajiban jangka pendek. Tabel 7 berikut menunjukan hasil perhitungan rasio likuiditas pada PT. Baramulti Sukses Sarana, Tbk.

Tabel 1. Hasil Perhitungan Rasio Likuiditas

\begin{tabular}{|c|l|l|l|l|l|l|}
\hline Jenis Rasio & $\mathbf{2 0 1 4}$ & $\mathbf{2 0 1 5}$ & $\mathbf{2 0 1 6}$ & $\mathbf{2 0 1 7}$ & $\mathbf{2 0 1 8}$ & $\mathbf{2 0 1 9}$ \\
\hline Current Ratio & 0.67 & 0.84 & 1.11 & 1.45 & 1.21 & 1.21 \\
\hline Quick Ratio & 0.52 & 0.72 & 1.00 & 1.35 & 1.00 & 1.01 \\
\hline Cash Ratio & 0.08 & 0.26 & 0.25 & 0.34 & 0.24 & 0.20 \\
\hline
\end{tabular}

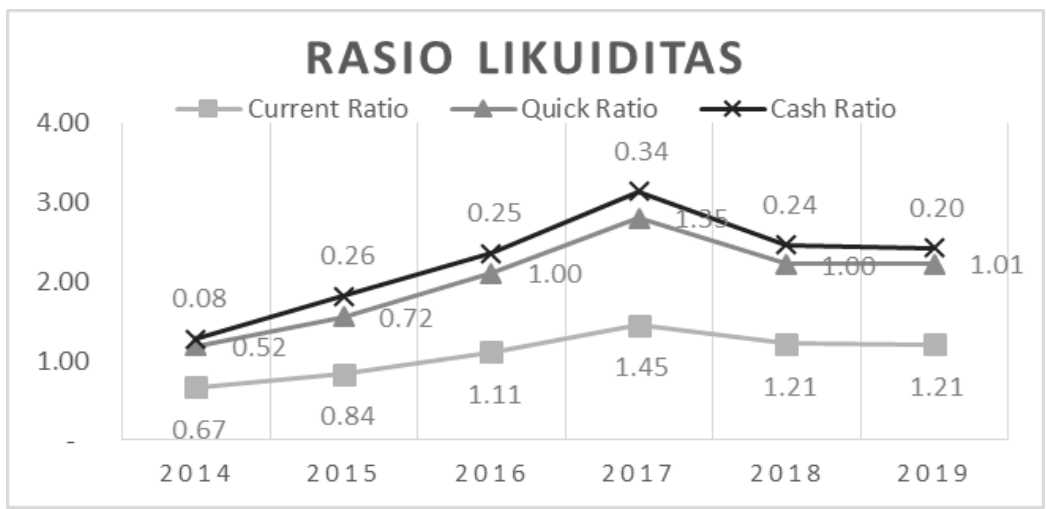

Gambar 1. Hasil Perhitungan Rasio Likuditas

1) Current Ratio 
Tabel 2. Perhitungan Current Ratio PT. BaramultiSukses Sarana, Tbk

\begin{tabular}{|r|r|r|r|}
\hline Tahun & Aktiva Lancar & Utang Lancar & \multicolumn{1}{|c|}{ Rasio } \\
\hline 2014 & $39,315,081$ & $58,642,244$ & 0.67 \\
\hline 2015 & $46,313,523$ & $55,450,256$ & 0.84 \\
\hline 2016 & $54,182,494$ & $48,895,237$ & 1.11 \\
\hline 2017 & $78,872,989$ & $54,430,580$ & 1.45 \\
\hline 2018 & $90,459,139$ & $74,454,433$ & 1.21 \\
\hline 2019 & $77,537,334$ & $64,264,652$ & 1.21 \\
\hline
\end{tabular}

Semakin tinggi current ratio maka semakin baik kinerja keuangan perusahaan tersebut. Berdasarkan data di atas milik PT Baramulti Sukses Sarana, Tbk terus mengalami peningkatan dengan perolehan perhitungan nilai current ratio pada tahun 2014 sebesar 0,67, tahun 2015 current ratio sebesar 0,84, tahun 2016 current ratio 1,11, tahun 2017 current ratio sebesar 1,45, tahun 2018 current ratio 1,21 dan pada tahun 2019 current ratio sebesar 1.21.

Peningkatan yang terus terjadi tersebut karena aspek dari hutang lancar seperti hutang bank jangka pendek, hutang usaha, hutang lain-lain, hutang pajak, hutang deviden dan hutang bank jangka panjang yang telah jatuh tempo mengalami penurunan nilai dari tahun 2014 hingga 2016 sedangkan dari tahun 2017 hingga 2019 terjadi peningkatan dari aspek aktiva lancar.

2) Quick Ratio

Tabel 3. Perhitungan Quick Ratio PT. BaramultiSukses Sarana, Tbk

\begin{tabular}{|r|r|r|r|r|}
\hline Tahun & Aktiva Lancar & \multicolumn{1}{|c|}{ Inventory } & Utang Lancar & Rasio \\
\hline 2014 & $39,315,081$ & $8,837,718$ & $58,642,244$ & 0.52 \\
\hline 2015 & $46,313,523$ & $6,370,826$ & $55,450,256$ & 0.72 \\
\hline 2016 & $54,182,494$ & $5,247,018$ & $48,895,237$ & 1.00 \\
\hline 2017 & $78,872,989$ & $5,545,199$ & $54,430,580$ & 1.35 \\
\hline 2018 & $90,459,139$ & $15,939,832$ & $74,454,433$ & 1.00 \\
\hline 2019 & $77,537,334$ & $12,366,729$ & $64,264,652$ & 1.01 \\
\hline
\end{tabular}

Semakin tinggi quick ratio maka semakin baik kinerja keuangan perusahaan tersebut. Berdasarkan data di atas milik PT Baramulti Sukses Sarana Tbk mengalami peningkatam hal ini mendapatkan perolehan perhitungan nilai quick ratio pada tahun 2014 sebesar 0,52, tahun 2015 quick ratio sebesar 0,72, tahun 2016 quick ratio 1,00. Pada tahun 2017 tingkat current ratio perusahan terus mengalami peningkatan mencapai rasio sebesar 1.35. Pada tahun 2018 quick ratio mengalami penurunan nilai mencapai rasio sebesar 1,00. Dan pada tahun 2019 mengalami kenaikan rasio dengan nilai 1.01. Penurunan quick ratio dari tahun 2017 sampai tahun 2018 disebabkan karena PT Baramulti Sukses Sarana Tbk memiliki prosentase persediaan yang lebih mendominasi dalam aset lancar, dengan adanya nilai persediaan yang mendominasi dibandingkan dengan komponen lain pada aset lancar 
mengakibatkan PT Baramulti Sukses Sarana Tbk dianggap kurang mampu mencairkan aktivanya menjadi kas dengan cepat.

3) Cash Ratio

Tabel 4. Perhitungan Cash Ratio PT. BaramultiSukses Sarana, Tbk

\begin{tabular}{|r|r|r|r|}
\hline Tahun & \multicolumn{1}{|c|}{ Kas } & Current Liabilities & \multicolumn{1}{|c|}{ Rasio } \\
\hline 2014 & $4,835,016$ & $58,642,244$ & 0.08 \\
\hline 2015 & $14,461,640$ & $55,450,256$ & 0.26 \\
\hline 2016 & $12,135,903$ & $48,895,237$ & 0.25 \\
\hline 2017 & $18,535,847$ & $54,430,580$ & 0.34 \\
\hline 2018 & $17,968,352$ & $74,454,433$ & 0.24 \\
\hline 2019 & $12,752,254$ & $64,264,652$ & 0.20 \\
\hline
\end{tabular}

Sumber : data diolah, 2020

Cash ratio menunjukkan perbandingan antara kas dan aktiva lancar yang bisa segera menjadi uang kas dengan hutang lancar. Dari hasil analisis terlihat bahwa cash ratio mengalami peningkatan dari tahun 2014 sebesar 0.08 menjadi 0,26 pada tahun 2015 dan turun menjadi 0.25 pada tahun 2016 . Penurunan ini disebabkan karena aktiva likuid dari tahun 2015 ke tahun 2016 mengalami penurunan yang diikuti juga dengan penurunan kewajiban lancar sebesar 11,82\%, Pada tahun 2017 cash ratio mengalami peningkatan kembali mencapai angka rasio 0.34. Pada tahun 2018 turun kembali mencapai angka rasio 0.24. Dan pada tahun 2019 rasio terus turun mencapai angka rasio 0.20 Sehingga dapat disimpulkan bahwa penurunan Cash Ratio menunjukkan kondisi perusahaan dalam keadaan kurang likuid, dan penurunan tingkat rasio menunjukkan penurunan kinerja perusahaan.

b. Rasio Solvabilitas

Rasio ini menggambarkan kemampuan perusahaan dalam pemenuhan semua kewajiban jangka pendek maupun jangka panjangnya apabila perusahaan dilikuidasi. Tabel 10 berikut menunjukkan hasil perhitungan rasio solvabilitas PT Baramulti Sukses Sarana, Tbk dari tahun 2014 - 2019.

Tabel 5. Hasil perhitungan Rasio Solvabilitas

\begin{tabular}{|c|c|c|c|c|c|c|}
\hline Jenis Rasio & $\mathbf{2 0 1 4}$ & $\mathbf{2 0 1 5}$ & $\mathbf{2 0 1 6}$ & $\mathbf{2 0 1 7}$ & $\mathbf{2 0 1 8}$ & $\mathbf{2 0 1 9}$ \\
\hline Debt Ratio & 0.46 & 0.40 & 0.31 & 0.29 & 0.39 & 0.32 \\
\hline $\begin{array}{c}\text { Debt Equity } \\
\text { Ratio }\end{array}$ & 0.86 & 0.66 & 0.44 & 0.40 & 0.63 & 0.47 \\
\hline
\end{tabular}




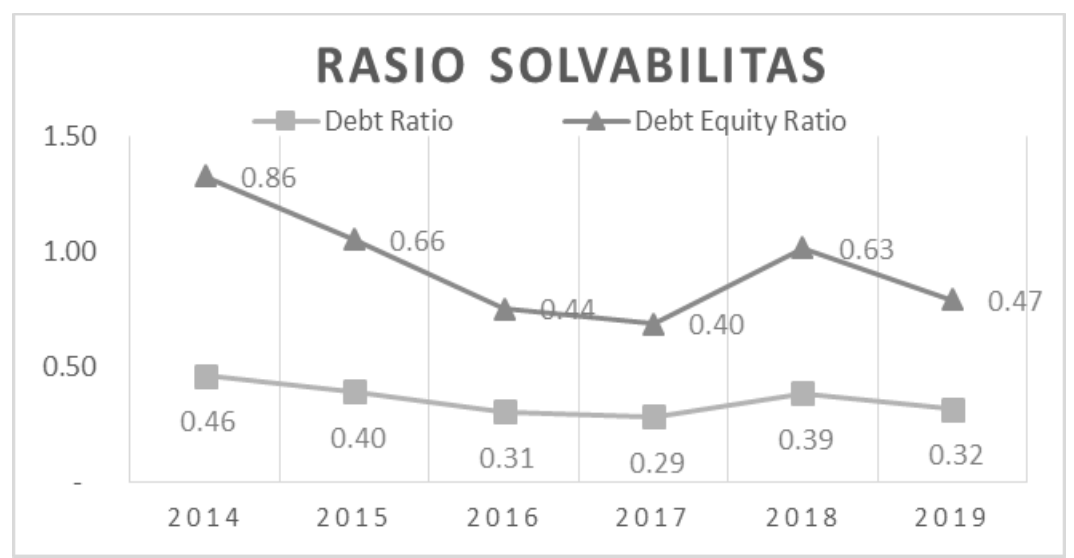

Gambar2. Hasil Perhitungan Rasio Solvabilitas

1) Debt Ratio

Tabel 6. Perhitungan Debt Ratio PT. BaramultiSukses Sarana, Tbk

\begin{tabular}{|r|r|r|r|}
\hline Tahun & \multicolumn{1}{|c|}{ Total Asset } & \multicolumn{1}{c|}{ Total Ekuitas } & \multicolumn{1}{c|}{$\begin{array}{c}\text { Debt Ratio } \\
\text { (kali) }\end{array}$} \\
\hline 2014 & $167,157,528$ & $89,704,181$ & 0.46 \\
\hline 2015 & $173,877,318$ & $104,951,376$ & 0.40 \\
\hline 2016 & $183,981,910$ & $127,345,381$ & 0.31 \\
\hline 2017 & $210,137,454$ & $149,890,675$ & 0.29 \\
\hline 2018 & $245,100,202$ & $150,279,337$ & 0.39 \\
\hline 2019 & $250,680,316$ & $170,317,658$ & 0.32 \\
\hline
\end{tabular}

Semakin rendah debt ratio maka semakin baik keadaan keuangan perusahaan. Berdasarkan data di atas milik PT Baramulti Sukses Sarana Tbk mengalami penurunan hal ini mendapatkan perolehan perhitungan nilai debt ratio pada tahun 2014 sebesar 46\%, tahun 2015 debt ratio sebesar 40\%. Pada tahun 2016 tingkat debt ratio perusahan mengalami penurunan sebesar 9\%. Pada tahun 2017 debt ratio PT Aneka Tambang (Persero) Tbk juga mengalami penurunan nilai sebesar 2\%. Pada tahun 2018 tingkat debt ratio perusahan mengalami peningkatan sebesar 10\%. Namun turun kembali pada tahun 2019 dengan nilai penurunan sebesar 7\%. Penurunan debt ratio dari tahun 2014 sampai tahun 2017 disebabkan oleh menurunnya nilai pinjaman pihak ketiga, dana pinjaman pengelolaan dan juga imbalan kerja.

2) Debt to Equity Ratio

Tabel 7. Perhitungan Debt to Equity Ratio PT. Baramulti Sukses Sarana, Tbk

\begin{tabular}{|r|r|r|r|r|}
\hline Tahun & Total Utang & Total Ekuitas & Rasio & $+/-$ \\
\hline 2014 & $77,453,347$ & $89,704,181$ & $86 \%$ & - \\
\hline 2015 & $68,925,942$ & $104,951,376$ & $66 \%$ & $-21 \%$ \\
\hline 2016 & $56,636,529$ & $127,345,381$ & $44 \%$ & $-21 \%$ \\
\hline 2017 & $60,246,779$ & $149,890,675$ & $40 \%$ & $-4 \%$ \\
\hline 2018 & $94,820,865$ & $150,279,337$ & $63 \%$ & $23 \%$ \\
\hline 2019 & $80,362,658$ & $170,317,658$ & $47 \%$ & $-16 \%$ \\
\hline
\end{tabular}


Semakin rendah debt to equity ratio menunjukkan kinerja yang baik bagi perusahaan. Berdasarkan data di atas milik PT. Baramulti Sukses Sarana Tbk mengalami kenaikan hal ini mendapatkan perolehan perhitungan nilai debt to equity ratio pada tahun 2014 sebesar 86\%, tahun 2015 debt to equity ratio sebesar 66\%, tahun 2016 debt to equity ratio sebesar 44\%, tahun 2017 debt to equity ratio sebesar 44\% . Pada tahun 2018 tingkat debt to equity ratio perusahan mengalami kenaikan sebesar 23\%. Pada tahun 2019 debt to equity ratio PT Aneka Tambang (Persero) Tbk mengalami penurunan nilai sebesar $16 \%$. Penurunan debt to equity ratio dari tahun 2014 sampai tahun 2017 disebabkan karena adanya penurunan pada komponen pinjaman pihak ketiga, dana jaminan pengelolaan lingkungan, dan penyisihan imbalan kerja sehingga menyebabkan nilai jumlah kewajiban jangka panjang menjadi lebih rendah. Peningkatan prosentase debt to equity ratio yang terjadi pada tahun 2018 dikarenakan komponen hutang jangka panjang yang lebih tinggi dibanding dengan tahun sebelumnya.

c. Rasio Aktivitas

Rasio ini digunakan untuk mengukur efektifitas perusahaan dalam penggunaan aktiva yang dimilikinya. Tabel 13 dibawah ini menggambarkan hasil perhitungan rasio aktivitas perusahaan PT. Baramulti Sukses Sarana, Tbk dari tahun 2014 - 2019.

Tabel 5. Hasil perhitungan Rasio Aktivitas

\begin{tabular}{|c|c|c|c|c|c|c|}
\hline Jenis Rasio & $\mathbf{2 0 1 4}$ & $\mathbf{2 0 1 5}$ & $\mathbf{2 0 1 6}$ & $\mathbf{2 0 1 7}$ & $\mathbf{2 0 1 8}$ & $\mathbf{2 0 1 9}$ \\
\hline $\begin{array}{c}\text { Inventory } \\
\text { Turnover }\end{array}$ & 19.23 & 26.77 & 31.52 & 39.94 & 17.94 & 24.88 \\
\hline $\begin{array}{c}\text { Receivable } \\
\text { Turnover }\end{array}$ & 8.93 & 10.64 & 6.95 & 7.62 & 8.28 & 8.27 \\
\hline $\begin{array}{c}\text { TotalAsset } \\
\text { Turnover }\end{array}$ & 1.30 & 1.49 & 1.32 & 1.87 & 1.81 & 1.67 \\
\hline
\end{tabular}

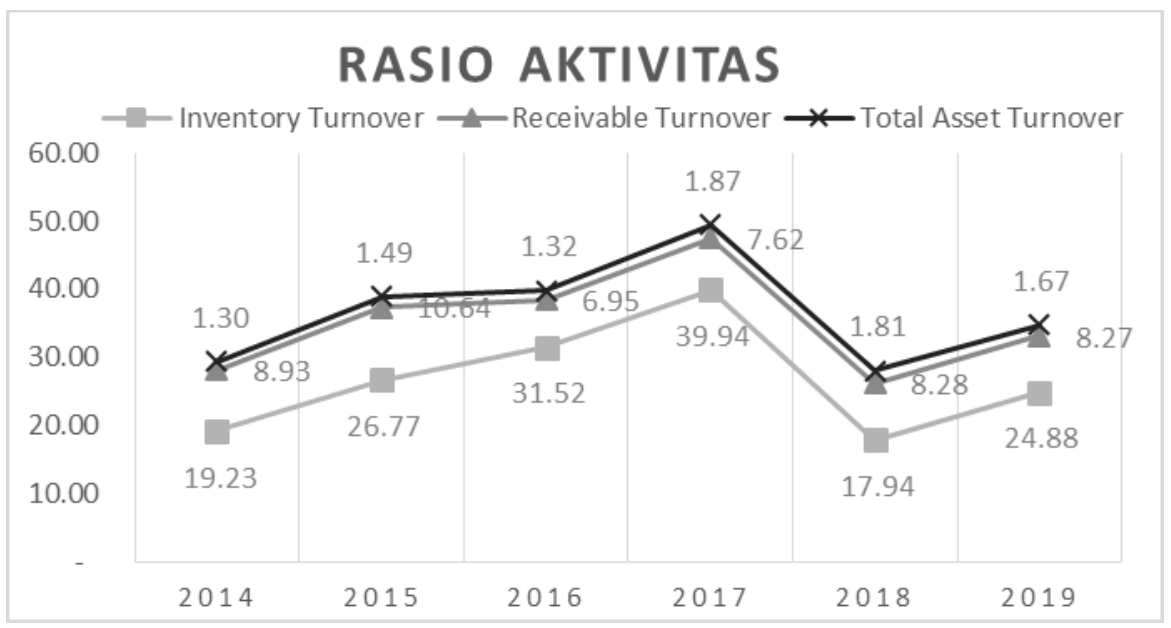

Gambar3. Hasil Perhitungan Rasio Aktivitas 
1) Inventory Turnover Ratio

Tabel 6. Perhitungan Inventory Turnover Ratio PT. Baramulti Sukses Sarana, Tbk

\begin{tabular}{|c|r|r|r|}
\hline Tahun & \multicolumn{1}{|c|}{ HPP } & \multicolumn{1}{|l|}{ Persediaan } & \multicolumn{1}{c|}{ Rasio } \\
\hline 2014 & $169,914,993$ & $8,837,718$ & 19.23 \\
\hline 2015 & $170,562,185$ & $6,370,826$ & 26.77 \\
\hline 2016 & $165,410,972$ & $5,247,018$ & 31.52 \\
\hline 2017 & $221,453,657$ & $5,545,199$ & 39.94 \\
\hline 2018 & $286,014,873$ & $15,939,832$ & 17.94 \\
\hline 2019 & $307,629,852$ & $12,366,729$ & 24.88 \\
\hline
\end{tabular}

Menurut Kasmir (2011:182), apabila nilai inventory turn over ratio dibawah standar maka perusahaan dinyatakan kurang baik karena perusahaan menahan persediaan dalam jumlah yang berlebih atau tidak produktif.

2) Receivable Turn Over Ratio

Tabel 7. Perhitungan Receivable Turn Over PT. BaramultiSukses Sarana, Tbk

\begin{tabular}{|l|r|r|r|}
\hline Tahun & Penjualan & \multicolumn{1}{|c|}{ Piutang } & \multicolumn{1}{c|}{ Rasio } \\
\hline 2014 & $217,110,403$ & $24,323,916$ & 8.93 \\
\hline 2015 & $259,020,747$ & $24,349,445$ & 10.64 \\
\hline 2016 & $242,598,535$ & $34,895,898$ & 6.95 \\
\hline 2017 & $392,574,134$ & $51,494,171$ & 7.62 \\
\hline 2018 & $443,432,403$ & $53,586,152$ & 8.28 \\
\hline 2019 & $418,087,491$ & $50,555,706$ & 8.27 \\
\hline
\end{tabular}

Semakin tinggi receivable turn over ratio menunjukkan bahwa modal kerja yang ditanamkan dalam piutang semakin rendah dan tentunya kondisi ini baik bagi perusahaan (Kasmir,2011:176). PT Baramulti Sukses Sarana, Tbk mengalami kenaikan dan penurunan hal ini mendapatkan perolehan perhitungan nilai receivable turn over ratio pada tahun 2014 sebesar 8,93 kali, tahun 2015 receivable turn over ratio sebesar 10,64 kali, tahun 2016 receivable turn over ratio 6,95 kali, tahun 2017 receivable turn over ratio 7,62 kali, tahun 2018 receivable turn over ratio 8,28 kali, tahun 2019 receivable turn over ratio 8,27 kali.

3) Total Assets Turn Over Ratio

Tabel 8. Perhitungan Total Assets Turn Over PT. BaramultiSukses Sarana, Tbk 


\begin{tabular}{|c|r|r|r|}
\hline Tahun & Penjualan & Total Asset & Total \\
\hline 2014 & $217,110,403$ & $167,157,528$ & 1.30 \\
\hline 2015 & $259,020,747$ & $173,877,318$ & 1.49 \\
\hline 2016 & $242,598,535$ & $183,981,910$ & 1.32 \\
\hline 2017 & $392,574,134$ & $210,137,454$ & 1.87 \\
\hline 2018 & $443,432,403$ & $245,100,202$ & 1.81 \\
\hline 2019 & $418,087,491$ & $250,680,316$ & 1.67 \\
\hline
\end{tabular}

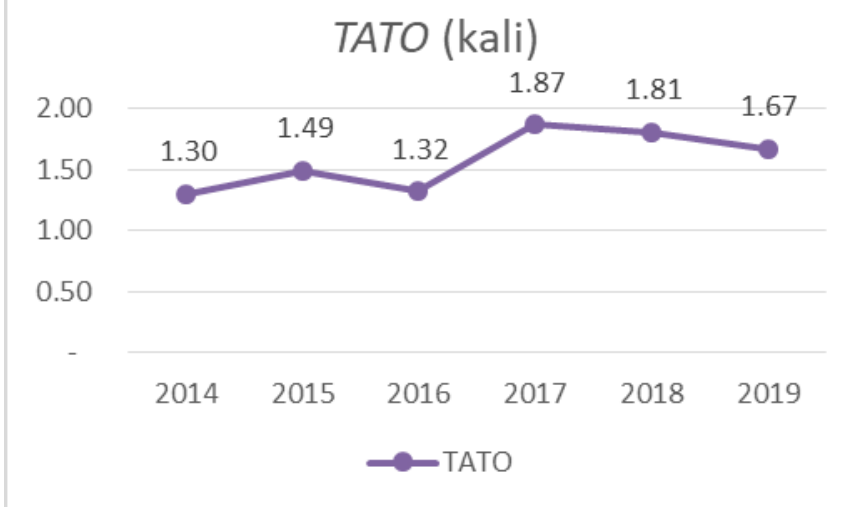

Gambar4. Hasil Perhitungan TATO

Berdasarkan data milik PT Baramulti Sukses Sarana Tbk mengalami penurunan hal ini mendapatkan perolehan perhitungan nilai total assets turn over ratio pada tahun 2014 sebesar 1,30 kali, tahun 2015 total assets turn over ratio sebesar 1,49 kali, tahun 2016 total assets turn over ratio 1,32 kali. Pada tahun 2017 tingkat total assets turn over ratio perusahan mengalami peningkatan mencapai angka 1.87 kali. Pada tahun 2018 total assets turn over ratio PT Baramulti Sukses Sarana Tbk mengalami penurunan mencapai rasio 1.81 kali dan turun terus pada tahun 2019 mencapai rasio 1.67 kali. Penurunan total assets turn over ratio dari tahun 2017 sampai tahun 2019 disebabkan karena turunnya nilai penjualan dari tahun 2018 sampai dengan tahun 2019 dan terjadinya kenaikan aset tetap setiap tahunnya.

d. Rasio Profitabilitas

Rasio ini digunakan untuk menunjukkan kemampuan perusahaan dalam menghasilkan keuntungan. Tabel 17 dibawah menggambarkan hasil perhitungan rasio profitabilitas perusahaan PT. Baramulti Sukses Sarana Tbk dari tahun 2014 - 2019.

Tabel 9. Hasil Perhitungan Rasio Profitabilitas

\begin{tabular}{|c|c|c|c|c|c|c|}
\hline Jenis Rasio & $\mathbf{2 0 1 4}$ & $\mathbf{2 0 1 5}$ & $\mathbf{2 0 1 6}$ & $\mathbf{2 0 1 7}$ & $\mathbf{2 0 1 8}$ & $\mathbf{2 0 1 9}$ \\
\hline Net Profit Margin & 1.17 & 10.18 & 11.30 & 21.10 & 15.57 & 7.29 \\
\hline Return on Asset & 1.52 & 15.17 & 14.90 & 39.41 & 28.18 & 12.15 \\
\hline Return on Equity & 2.84 & 25.13 & 21.53 & 55.25 & 45.96 & 17.89 \\
\hline
\end{tabular}




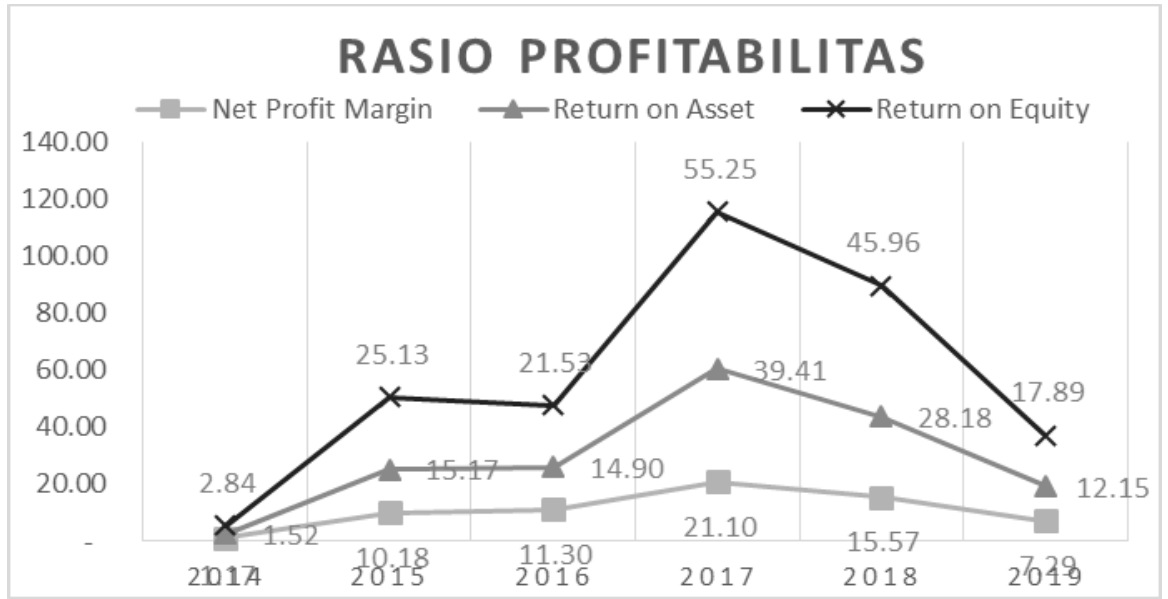

Gambar 5. Hasil Perhitungan Rasio Profitabilitas

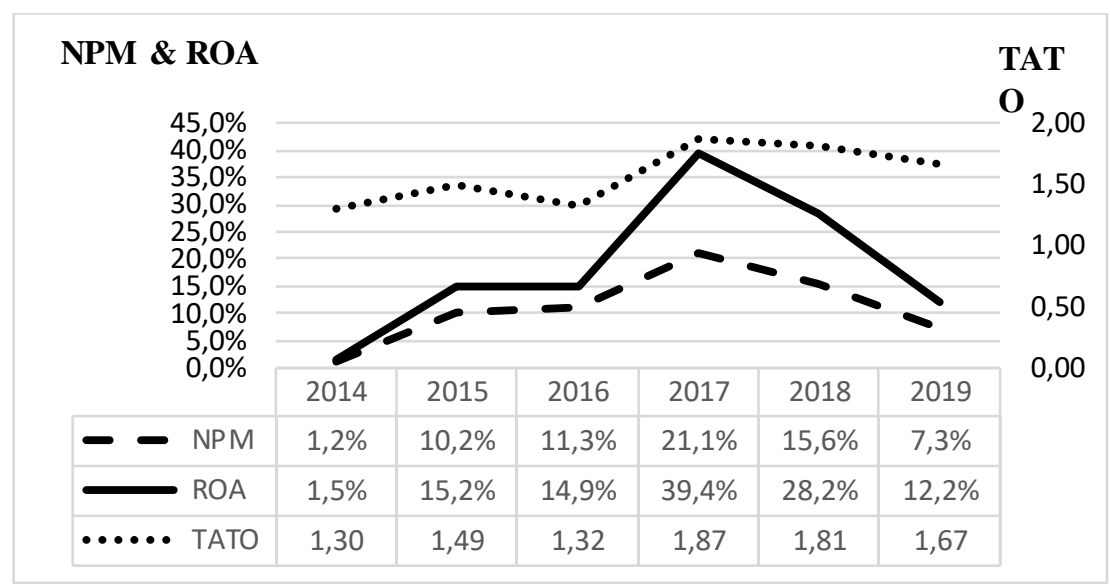

Gambar6. Hasil Perhitungan ROA, NPM dan TATO

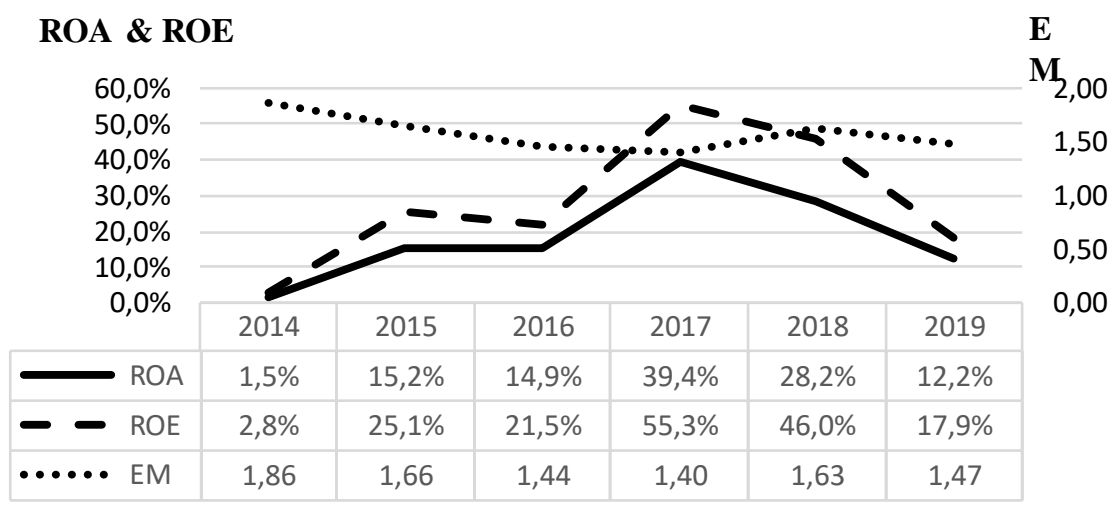

Gambar7. Hasil Perhitungan ROA, ROE dan EM 
1. Net Profit Margin

Tabel 9. Hasil Perhitungan Net Profit Margin

\begin{tabular}{|r|r|r|r|}
\hline Tahun & \multicolumn{1}{|c|}{ Laba Bersih } & Penjualan & \multicolumn{1}{c|}{ Rasio } \\
\hline 2014 & $2,544,925$ & $217,110,403$ & 1.17 \\
\hline 2015 & $26,376,125$ & $259,020,747$ & 10.18 \\
\hline 2016 & $27,421,577$ & $242,598,535$ & 11.30 \\
\hline 2017 & $82,816,929$ & $392,574,134$ & 21.10 \\
\hline 2018 & $69,063,191$ & $443,432,403$ & 15.57 \\
\hline 2019 & $30,467,457$ & $418,087,491$ & 7.29 \\
\hline
\end{tabular}

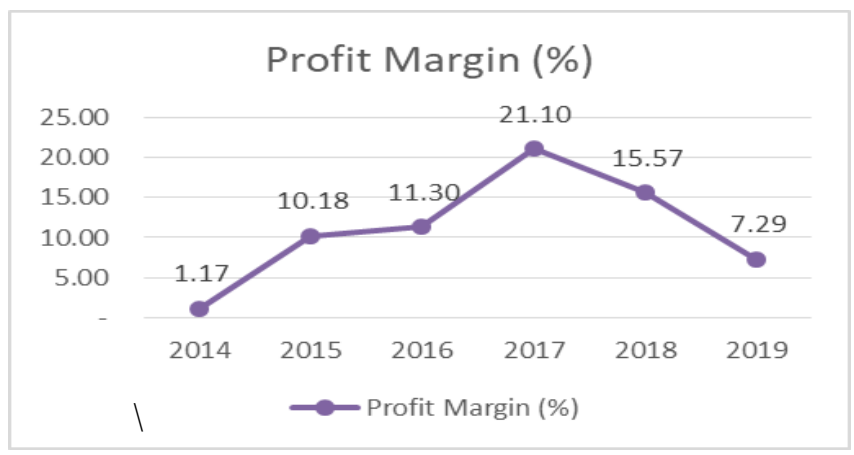

Gambar 8. Hasil Perhitungan Profit Margin

Semakin tinggi net profit margin maka akan menunjukkan semakin baik kinerja keuangan yang dicapai perusahaan. Berdasarkan data di atas milik PT Baramulti Sukses Sarana Tbk mengalami penurunan hal ini mendapatkan perolehan perhitungan nilai net profit margin pada tahun 2014 sebesar 1.17\%, tahun 2015 net profit margin sebesar 10.18\%, tahun 2016 net profit margin 11.30\%. Pada tahun 2017 tingkat net profit margin perusahan mengalami peningkatan mencapai rasio $21.10 \%$, tahun 2018 turun kembali mencapai rasio $15.57 \%$ dan pada tahun 2019 terus turun mencapai rasio 7.29\%. Penurunan net profit margin dari tahun 2017 sampai tahun 2019 disebabkan karenadari tahun 2017 sampai dengan tahun 2019 penerimaan laba setelah pajak oleh perusahaan semakin menurun.

2. Return on Asset

Tabel 10. Perhitungan Return on Asset PT. BaramultiSukses Sarana, Tbk

\begin{tabular}{|r|r|r|r|}
\hline Tahun & \multicolumn{1}{|c|}{ NPM } & \multicolumn{1}{|c|}{ TATO } & \multicolumn{1}{|c|}{ Total } \\
\hline 2014 & 1.17 & 1.30 & 1.52 \\
\hline 2015 & 10.18 & 1.49 & 15.17 \\
\hline 2016 & 11.30 & 1.32 & 14.90 \\
\hline 2017 & 21.10 & 1.87 & 39.41 \\
\hline 2018 & 15.57 & 1.81 & 28.18 \\
\hline 2019 & 7.29 & 1.67 & 12.15 \\
\hline
\end{tabular}




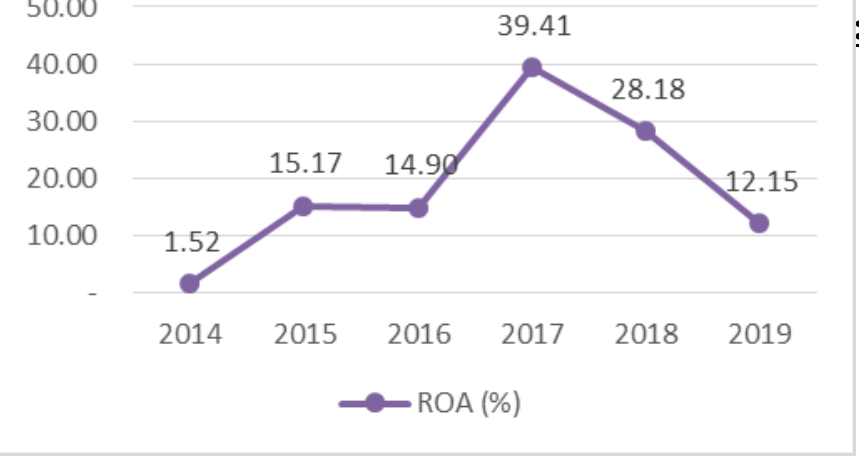

Gambar9. Hasil Perhitungan ROA

Semakin tinggi return on asset maka akan menunjukkan semakin baik kinerja keuangan yang dicapai perusahaan. Berdasarkan data di atas milik PT Baramulti Sukses Sarana Tbk mengalami peningkatan hal ini mendapatkan perolehan perhitungan nilai return on asset pada tahun 2014 sebesar 1,52\%, tahun 2015 return on asset sebesar 15,17\%, tahun 2016 return on asset 14,90. Pada tahun 2017 tingkat return on asset perusahan mengalami peningkatan menjadi 39,41\%. Pada tahun 2018 return on asset PT Baramulti sukses Sarana Tbk mengalami penurunan nilai menjadi 28,18\%. Dan pada tahun 2019 turun kembali dengan rasio $12,15 \%$.

3. Return on equity

Tabel 11. Perhitungan Return on Equity PT. BaramultiSukses Sarana, Tbk

\begin{tabular}{|r|r|r|r|}
\hline Tahun & Laba Bersih & Total Equity & Rasio \\
\hline 2014 & $2,544,925$ & $89,704,181$ & $3 \%$ \\
\hline 2015 & $26,376,125$ & $104,951,376$ & $25 \%$ \\
\hline 2016 & $27,421,577$ & $127,345,381$ & $22 \%$ \\
\hline 2017 & $82,816,929$ & $149,890,675$ & $55 \%$ \\
\hline 2018 & $69,063,191$ & $150,279,337$ & $46 \%$ \\
\hline 2019 & $30,467,457$ & $170,317,658$ & $18 \%$ \\
\hline
\end{tabular}

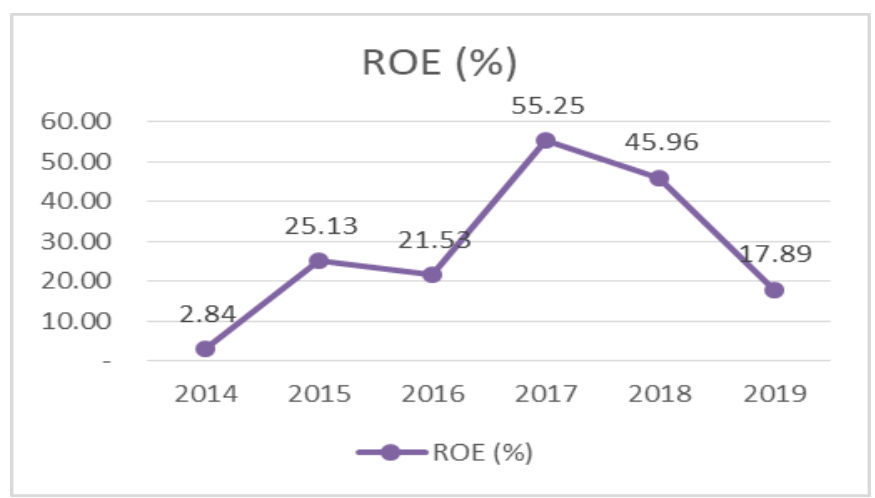

Gambar 10. Hasil Perhitungan ROE

Semakin tinggi return on equity maka akan menunjukkan semakin baik kinerja keuangan yang dicapai perusahaan. Berdasarkan data di atas milik PT Baramulti Sukses Sarana Tbk mengalami penurunan dan peningkatan hal ini mendapatkan 
perolehan perhitungan nilai return on equity pada tahun 2014 sebesar 3\%, tahun 2015 return on equity sebesar 25\%, tahun 2016 return on equity $22 \%$. Pada tahun 2017 tingkat return on equity perusahan mengalami peningkatan mencapai rasio 55\%. Pada tahun 2018 return on equity Baramulti Sukses Sarana Tbk mengalami penurunan nilai rasio mencapai 46\% dan pada tahun 2019 turun lagi mencapai rasio 19\%. Penurunan return on equity dari tahun 2017 sampai tahun 2019 disebabkan karena tidak seimbangnya peningkatan nilai baik laba bersih maupun jumlah ekuitas, jika salah satu komponen dalam laba bersih tidak meningkat, maka komponen dalam ekuitas juga ikut menurun sehingga dapat menyebabkan nilai return on equity tidak stabil cenderung terus menurun.

\section{Analisis Kinerja Keuangan}

Berikut ini adalah analisis Du Pont System:

Tabel 12. Analisis Kinerja Keuangan pada perusahaan PT. Baramulti Sukses Sarana Periode $2014-2019$

\begin{tabular}{|c|c|c|c|c|}
\hline \multirow{2}{*}{ Tahun } & TATO & $N P M$ & $R O A$ & ROE \\
\hline & (Kali) & $(\%)$ & $(\%)$ & $(\%)$ \\
\hline 2014 & 1.30 & 1.17 & 1.52 & 2.84 \\
\hline 2015 & 1.49 & 10.18 & 15.17 & 25.13 \\
\hline 2016 & 1.32 & 11.30 & 14.90 & 21.53 \\
\hline 2017 & 1.87 & 21.10 & 39.41 & 55.25 \\
\hline 2018 & 1.81 & 15.57 & 28.18 & 45.96 \\
\hline 2019 & 1.67 & 7.29 & 12.15 & 17.89 \\
\hline Rata-Rata & 1.58 & 11.10 & 18.56 & 28.10 \\
\hline
\end{tabular}

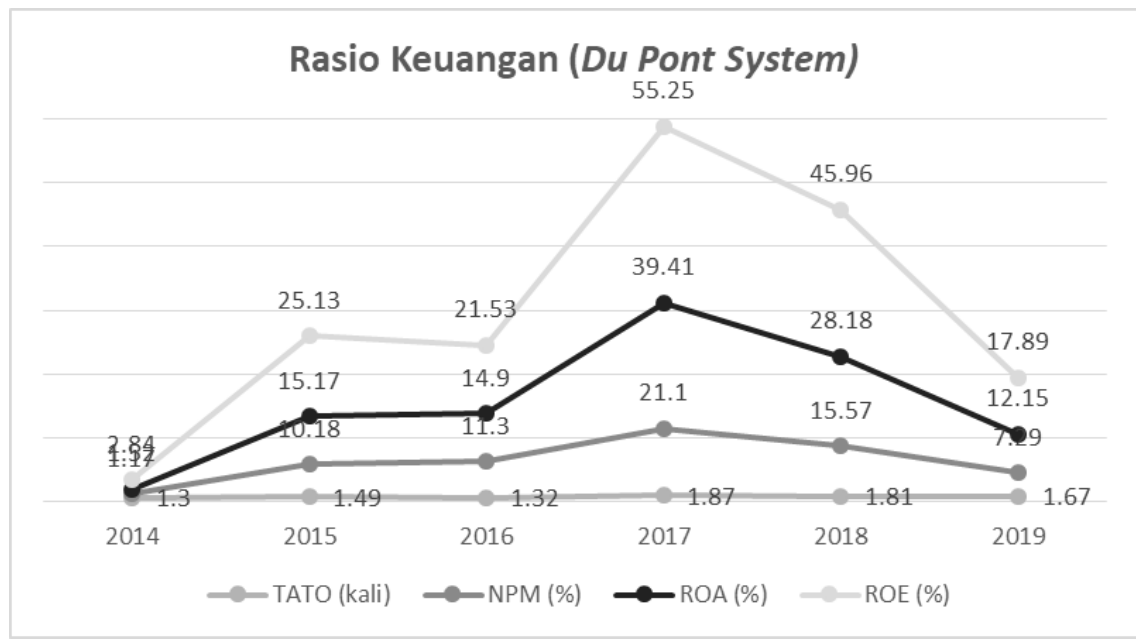

Gambar11. Rasio Keuangan

Dari angka-angka yang didapat menggunakan berbagai macam perhitungan dapat dilihat ada beberapa hal yang harus diperhatikan perusahaan di masa yang akan datang. Perusahaan pasti menginginkan nilai ROE semakin tinggi. Sementara di sisi lain ROE dipengaruhi oleh ROA dan Total Asset Turnover. Kinerja keuangan perusahaan PT Baramulti Sukses Sarana dari tahun 2014 - 2019 mengalami kondisi yang kurang baik. 
Dapat dilihat dari nilai NPM yang masih fluktuatif dan bahkan masih berada dibawah standar industri. Sedangkan untuk nilai ROA pada perusahaan PT Baramulti Sukses Sarana juga dengan kondisi fluktuatif setiap tahun dan dibawah standar industri. Atas dua faktor tersebut yang cenderung naik turun berimbas pada nilai Return On Equity yang fluktuatif.

\section{KESIMPULAN}

Berdasarkan hasil analisis dan pembahasan, maka penulis dapat menarik kesimpulan bahwa:

1. Kemampuan perusahaan PT. Baramulti Sukses Sarana dalam pemenuhan kewajiban jangka pendek dari tahun 2014 - 2019 mengalami kondisi yang membaik setiap tahunnya meskipun masih dibawah standar ind sutri.

2. Kemampuan perusahaan PT. Baramulti Sukses Sarana dalam pemenuhan semua kewajiban jangka pendek maupun jangka panjangnya apabila perusahaan dilikuidasi juga menunjukkan kondisi yang baik. Terlihat dari penurunan angka rasio dari tahun 2014 hingga 2019.

3. Kemampuan perusahaan PT. Baramulti Sukses Sarana dalam mengukur efektifitas perusahaan dalam penggunaan aktiva yang dimilikinya masih dalam kondisi yang kurang baik. Terlihat dari angka rasio yang fluktuatif setiap tahun dan masih dibawah standar industri.

4. Kemampuan perusahaan PT. Baramulti Sukses Sarana dalam menghasilkan keuntungan masih dalam kondisi yang kurang baik. Meskipun angka rasio menunjukkan peningkatan dari tahun 2014 - 2016 namun tidak bertahan stabil hingga tahun 2019. Kondisi ini menunjukkan perusahaan masih kurang mampu menghasilkan laba secara maksimal setiap tahun.

5. Kinerja perusahaan pada PT. Baramulti Sukses Sarana, Tbk berdasarkan analisa $d u$ pont system selama enam tahun dari tahun 2014 sampai dengan tahun 2019 mengalami angka yang fluktuatif pada beberapa rasio meskipun di tahun 2014 hingga 2016 menunjukkan peningkatan setiap tahunnya akan tetapi dengan terjadinya penurunan dari tahun 2017 2019 membuktikan bahwa perusahaan masih kurang mampu melakukan efektifitas semua sumber daya perusahaan untuk mencapai peningkatan laba secara maksimal.

\section{DAFTAR PUSTAKA}

Almazari, A. A. 2012. Financial Performance Analysis of the Jordanian Arab Bank by Using the DuPont System of Financial Analysis. International Journal of Economics and Finance Vol. 4 No. 4: 86 - 94.

Darmawan Sjahrial. 2009. Manajemen Keuangan. Edisi 3 Mitra Wacana Media. Jakarta

Fahmi, Irham. 2013. Analisa Laporan Keuangan. Bandung: Alfabeta.

Herciu, M., Ogrean, C., dan Belascu, L. 2011. A Du Pont Analysis of the 20 Most Profitable Companies in the World. IACSIT, Vol.1: $45-48$

Ikatan Akuntansi Indonesia (IAI). 2013. PSAK, No.1. Jakarta 
Kasmir. 2012. Analisis Laporan Keuangan.Rajawali Pers: Jakarta.

---, 2014. Analisis Laporan Keuangan Edisi 1-7. Jakarta: PT. Grafindo Persada

Keown, J. A., Scott, F. D. Jr., Martin, D. J., \& Pretty W. J. 2001. Dasar-dasar Manajemen Keuangan, Edisi Ketujuh. Salemba Empat, Jakarta

Munawir. 2012. Analisis Laporan Keuangan Edisi Keempat. Yogyakarta: Liberty.

Rhardjo, Budi. 2007. Keuangan dan AkuntansiEdisi Pertama Cetakan Pertama. Yogyakarta: Graha Ilmu.

Suhartadi, Purwanto S. 2013. Statistika untuk Ekonomi dan Keuangan Modern. Jakarta: Salemba Empat.

Surat KepMen BUMN No.KEP-100/KBU/2002

Taswan. 2013. Akuntansi Perbankan. Edisi III Cetakan 3 UPP STIM YKPN. Yogyakarta

Trijono, Achmat. 2015. Penelitian Kuantitatif. Depok: Papas Sinar Saninanti.

Undang-undangNomor 19 Tahun 2003 Tentang Badan Usaha Milik Negara 